\title{
Comparative Study of Daylighting Calculation Methods
}

\author{
Ariani Mandala ${ }^{1, *}$ and Amirani Ritva Santoso ${ }^{1}$ \\ ${ }^{1}$ Lecturer at Department of Architecture, Universitas Katolik Parahyangan, Indonesia.
}

\begin{abstract}
The aim of this study is to assess five daylighting calculation method commonly used in architectural study. The methods used include hand calculation methods ( SNI/DPMB method and BRE Daylighting Protractors), scale models studied in an artificial sky simulator and computer programs using Dialux and Velux lighting software. The test room is conditioned by the uniform sky conditions, simple room geometry with variations of the room reflectance (black, grey, and white color). The analyses compared the result (including daylight factor, illumination, and coefficient of uniformity value) and examines the similarity and contrast the result different. The color variations trial is used to analyses the internally reflection factor contribution to the result.
\end{abstract}

Keywords: daylighting methods, daylight factor, room reflection

\section{Introduction}

Daylighting has a great potential to do energy saving in buildings. Daylighting calculation is becoming the valuable need for the designer to optimize its potential in architectural design. Hopkinson (1966) cited by Acosta (2011) in his book Daylighting reveals the complexity of the calculation procedure in daylighting. Currently, a designer has many options in using the daylighting calculation methods. Until now, hand-calculation method with graphics and diagrams still used because of its versatility in use. A scale model simulation still remains to become one of the choice because it is a familiar method used in architectural design and also provides a representative object for presentation media. The emergence of a variety of specialized software for lighting (daylight and artificial light) allows designers to have a more complete and complex analysis of the lighting condition through a digital simulation. A wide choice of these calculation methods helps designers to choose the method that suits the design needs.

Different calculation methods also give a difference in the result. This is caused by many factors, each methods have their capable of accommodating the complexity daylighting calculation factor and the difference of calculation algorithm. This research aimed to evaluate several methods of calculation of dayighting that are commonly used in architectural education. The methods used include hand method calculation with SNI/DPMB method, calculation with a BRE protractor (Building Research Establishment), the scale model simulation on artificial sky and simulation software using Dialux and Velux program.

This study is limiting the daylighting calculation parameter to avoid the overly variation result and produce preciser calculation. A room model used in this research is a simple geometry with one side opening (window). Simulation is done in the overcast sky conditions to avoid the complexity of direct sunlight effect to the result. A room reflectance trial also simulates in this research using a different color in the room surface (black, gray, and white). Analysis of the comparative form of daylighting conditions includes the Daylight Factor value, illumination, and light distribution (pattern and uniformity). The room surface color trial will be analyzed to reveal its role in daylighting performance.

This research was conducted with several aims. First is to assess and compare the various methods of calculation that mentioned above with analyzing the similarities and differences of daylighting calculation result using daylight factor (DF) value and coefficient of uniformity (CU) value of those methods. Second is to study the room reflectance contribution to daylighting performance. This research is expected to provide the following benefits. The findings can be a learning material to optimizing daylighting design in architectural study and also becomes a valuable input for updating the national lighting standard in Indonesia. The analyses of the reflection factor contribution can be developed to be a practical guide to optimize the daylighting potential in the building design.

\section{Daylighting Calculation Methods}

Factors that affect the appearance in visual activities are types of activity, lighting conditions, and the observer's condition (Lechner, 2007:386). The level of illumination is one of the factors in lighting conditions that most frequently observed and easily measured. With the daylighting design, illumination is often associated with the concept of daylight factor. DF is the ratio of the illumination in the inside (room) and the outside counted in percentage. The measurement

* Corresponding author: ariani.mandala@unpar.ac.id 
conditioned in a cloudy/overcast sky (uniform illumination) to minimize lighting level fluctuations caused by direct sunlight in different dates and times. In daylighting design, uniformity of lighting distribution is difficult to achieve. Artificial lighting source can easily be organized and modified. Daylighting source (an opening / window that brings the sunlight) has limitations so that various strategies need to be applied to obtain the uniform light distribution. Coefficient of Uniformity/CU is used to rate the light distribution. $\mathrm{CU}$ is the ratio of minimum and maximum illumination in a room.

There are three main components in the daylighting calculation, the Sky Component (SC) the Externally Reflection Component (ERC) and the Internally Reflection Component (IRC). This study calculates SC and IRC components into the calculation. ERC is not included into this trial.

The hand method calculation used in the study is SNI and BRE methods. The SNI calculation method refers to the national standard that applies in Indonesia. SNI (Standar Nasional Indonesia) is issued by the national standardization institution in the form of SNI 03-2396-2001 about the daylighting design system in a building. SNI method only accommodates sky component without internally and externally component. BRE (Building Research Establishment), which was formerly called BRS developed series protractor to read the percentage value of sky component. The BRE calculation method can calculate the SC and the ERC. BRE also have a Nomogram that was able to complete the calculation with components of the IRC. This research using the uniform sky protractor series to calculate SC and Nomogram to calculate the components of the IRC.

A scale model measurement is done in an artificial sky simulator. Testing on an artificial sky allows to get the more consistent results compared to testing in the real sky. A study by Acosta was done in 2011 when he compared the daylighting calculation methods in artificial sky and lighting software (Lightscape, Radiance, Lumen Micro, Ecotec, and Dialux). As a result, the value of DF from measurements using artificial sky is relatively larger than the software. While the value of the CU relative approach. In this study, testing done in the artificial sky simulator in laboratory of building physics belonging to Parahyangan Catholic University. The room has hexagonal-shaped in white paint, roof dome shape and uses mirrors around the room in. 18 pcs of white fluorescent lamps used as a representation of the skylight. Three models were made in 1:20 scale. The inside of each model painted with black, gray, and white for testing with the room reflection trial. Two digital lightmeter was used to measure the illumination inside and outside the building at the same time.

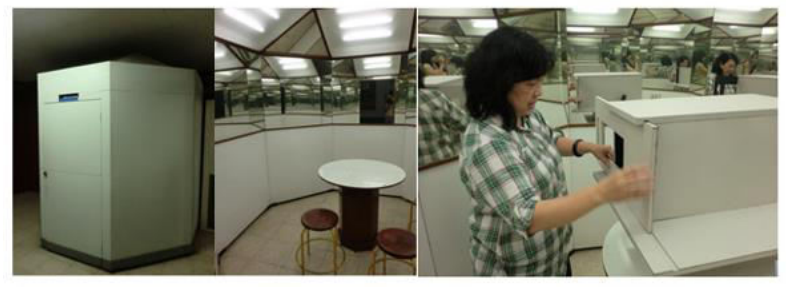

Fig. 1. Artificial sky trial simulator.

Software used in this research are Dialux and Velux. These programs used with consideration of ease of use. Iversen (2013) revealed that Dialux and Velux is a program with an easy to learn compared to other programs such as Radiance, Desktop Radiance, and Daysim. Another consideration is that both programs do not require a license and can be easily downloaded via the official website. The fundamental difference of these two software is the calculation methods / rendering type. Velux using photon mapping (bi-directional ray tracing) while Dialux using the radiosity rendering to calculate the result. Photon mapping calculation is able to optimize the simulation so that it can be used for more complex lighting scenarios, such as light pipes, and faster than the previous way backward ray tracing. While radiosity renderation is excellent for the application of translucent material with a spreads light source and also efficient to simulate the light distribution in space. But it has limitations in simulating natural lighting and can only be used for evaluation of space with simple shapes (Iversen, 2013).

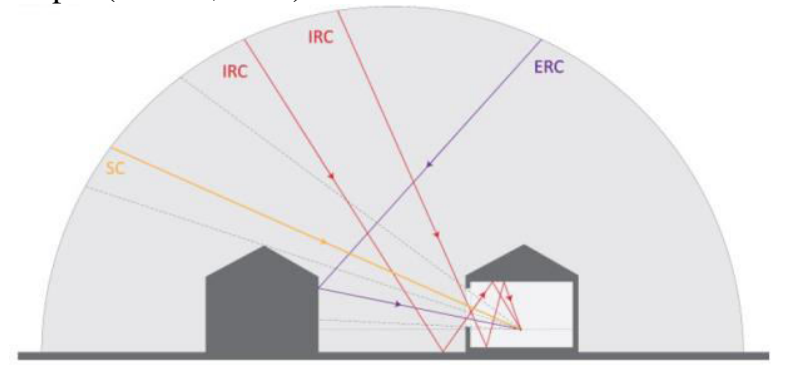

Fig. 2. Split flux formula's components. Source: Iversen, 2013.

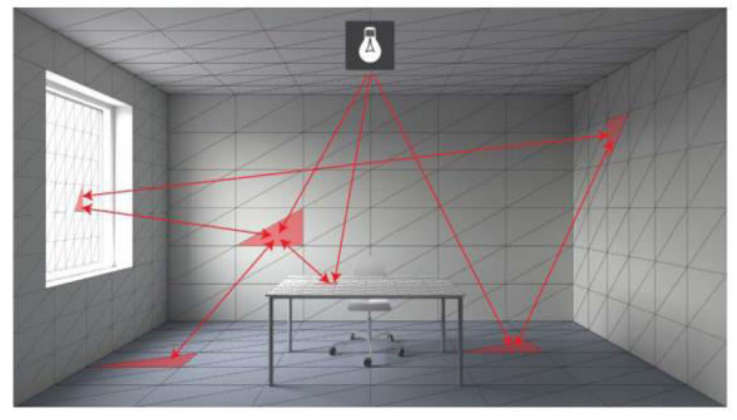

Fig. 3. Radiosity calculation method.

Source: Iversen, 201. 


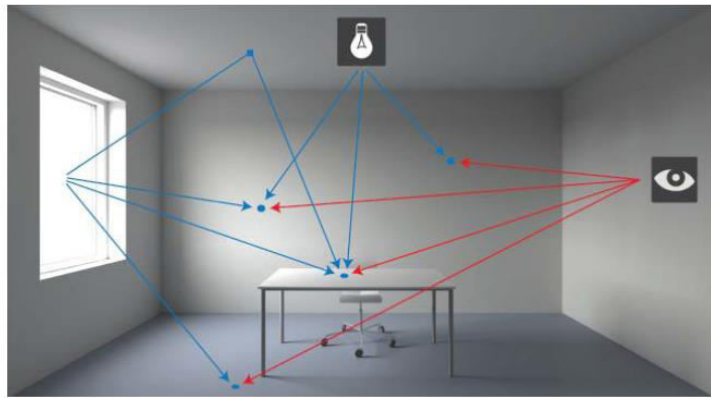

Fig. 4. Photton mapping calculation method. Source: Iversen, 2013.

\section{Research Methods}

This research will compare calculations result of DF and CU by five daylighting calculation methods. Each method has limitations in the accommodating the daylight parameter. This study will limit the parameters required so that it can be accommodated by all the calculation methods. We used a square-shaped room model of $8 \times 8 \times 4.5$ meters with an opening on one of its sides (Figure 4). Three models were made with different color surface for room reflection trial. We used white color (reflection factor $70 \%$ ), gray (reflection factor $30 \%$ ) and black (reflection factor 4\%). The opening of $3,5 \times 6,30$ meters is centered on one side and has no filter so the light can enter the room completely.

There were 12 calculation points $(\mathrm{CP})$ with $80 \mathrm{~cm}$ height, spread in the room in a grid pattern. The maximum illumination level is on $\mathrm{CP} 2$, and the minimum illumination level is on CP 10 or CP 12 (because of its symmetrical shape). The measurement points position can be seen in Figure 4.

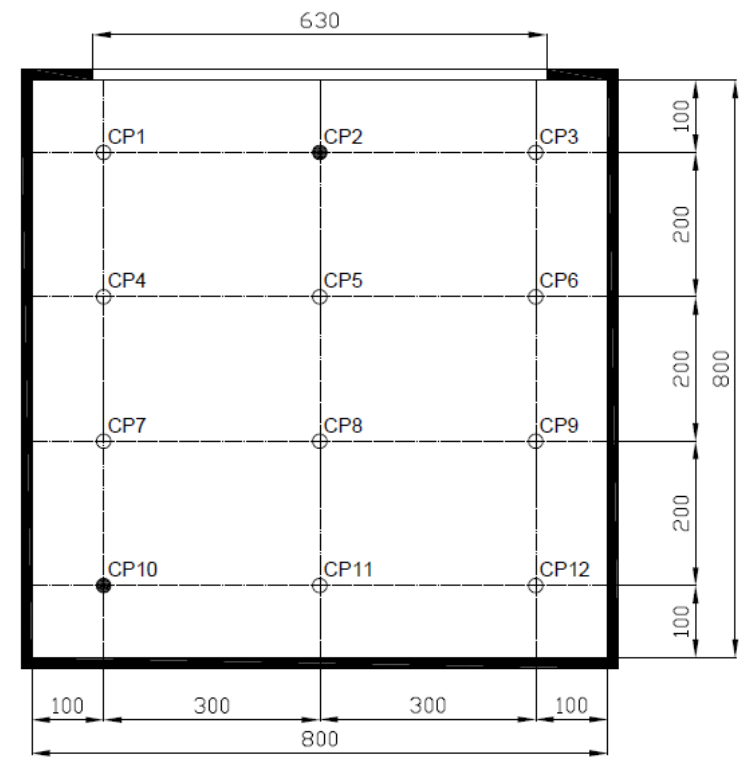

Fig. 4. Calculation points plan.
Table 1. Daylighting Calculation Parameters.

\begin{tabular}{|c|c|c|c|}
\hline \multicolumn{3}{|c|}{ Factors } & Varian \\
\hline \multirow{3}{*}{$\begin{array}{l}\text { Sky } \\
\text { Condition }\end{array}$} & \multicolumn{2}{|l|}{ Time } & June, 21st 2017 \\
\hline & \multicolumn{2}{|c|}{ Geographical position } & $\begin{array}{l}\text { Bandung City } \\
\left(6^{0} \mathrm{~S}\right)\end{array}$ \\
\hline & \multicolumn{2}{|c|}{ Sky component } & Overcast \\
\hline \multirow{11}{*}{ Building } & \multicolumn{2}{|c|}{ Room geometry } & $\begin{array}{l}\text { Room orientation: } \\
\text { North opening } \\
\text { Room shape: square } \\
\text { Room dimensions: } 8 \\
\text { m x } 8 \mathrm{~m} \\
\end{array}$ \\
\hline & \multirow[t]{2}{*}{ Window } & $\begin{array}{l}\text { Window } \\
\text { geometry }\end{array}$ & $\begin{array}{l}\text { Window orientation: } \\
\text { facing north } \\
\text { Position: center } \\
\text { Qty: } 1 \text { pcs } \\
\text { Shape: rectangle } \\
\text { Dimension: } 6.3 \text { x } 3.15 \\
\text { m }\end{array}$ \\
\hline & & Material & $\begin{array}{l}\text { Transparency: } 100 \% \\
\text { Reflection \& texture: } \\
\text { none }\end{array}$ \\
\hline & \multirow[t]{2}{*}{$\begin{array}{l}\text { Reflection } \\
\text { factor }\end{array}$} & $\begin{array}{l}\text { Internally } \\
\text { reflection }\end{array}$ & $\begin{array}{l}\text { Ceiling, wall, floor } \\
\text { surface color: black (e } \\
=4 \%) \text {, gray }\left({ }_{e}=30 \%\right) \\
\text { and white }\left({ }_{e}=70 \%\right)\end{array}$ \\
\hline & & $\begin{array}{l}\text { Externally } \\
\text { reflection }\end{array}$ & None \\
\hline & \multicolumn{2}{|c|}{$\begin{array}{l}\text { Artificial lighting } \\
\text { contribution }\end{array}$} & None \\
\hline & \multirow[b]{2}{*}{ Shading } & Internal & None \\
\hline & & External & $\begin{array}{l}\text { Wall thickness: } \\
15 \mathrm{~cm}\end{array}$ \\
\hline & \multicolumn{2}{|c|}{ Maintenance } & None \\
\hline & \multicolumn{2}{|l|}{ Pollution } & None \\
\hline & \multicolumn{2}{|l|}{ Furniture } & None \\
\hline
\end{tabular}

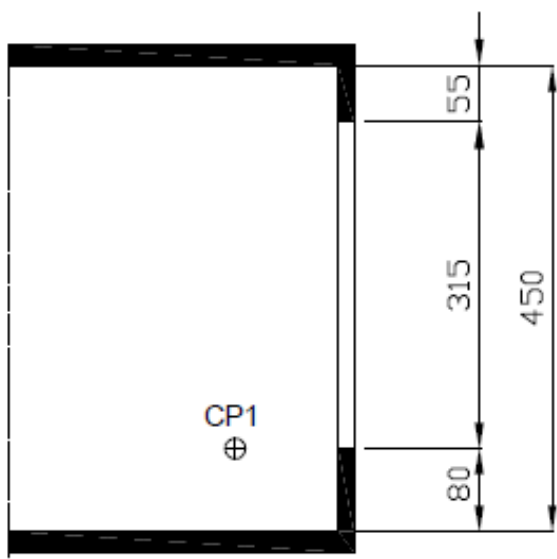

Fig. 5. Models' section.
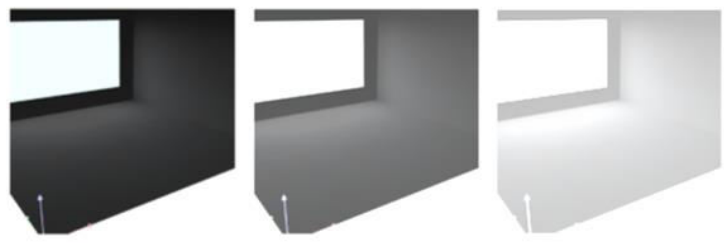

Fig. 6. Model simulations with color variations of the surface material. 
Table 2. Calculation parameter of each method.

\begin{tabular}{|c|c|c|}
\hline \multicolumn{3}{|c|}{ Hand calculation: SNI } \\
\hline $\begin{array}{l}\text { Calculation } \\
\text { type }\end{array}$ & & $\mathrm{SC} \& \mathrm{E}$ \\
\hline Sky condition & & Uniform (10.000 Lux) \\
\hline $\begin{array}{l}\begin{array}{l}\text { Room } \\
\text { material }\end{array} \\
\end{array}$ & $\begin{array}{l}\text { Internally } \\
\text { reflection } \\
\end{array}$ & Black $(e=0 \%)$ \\
\hline Window & & No filter \\
\hline \multicolumn{3}{|c|}{ Hand calculation: BRE } \\
\hline $\begin{array}{l}\text { Calculation } \\
\text { type }\end{array}$ & & DF \& E \\
\hline Sky condition & & Uniform (10.000 Lux) \\
\hline Protractor & & $\begin{array}{l}\text { Uniform sky-vertical } \\
\text { glazing }\end{array}$ \\
\hline $\begin{array}{l}\text { Room } \\
\text { material }\end{array}$ & $\begin{array}{l}\text { Internally } \\
\text { reflection }\end{array}$ & $\mathrm{e}=4 \%, 30 \%, 70 \%$ \\
\hline \multicolumn{3}{|c|}{ Artificial sky simulator } \\
\hline $\begin{array}{l}\text { Calculation } \\
\text { type }\end{array}$ & & $\mathrm{DF} \& \mathrm{E}$ \\
\hline Sky condition & & Uniform sky \\
\hline $\begin{array}{l}\text { Room } \\
\text { material }\end{array}$ & $\begin{array}{l}\text { Internally } \\
\text { reflection }\end{array}$ & $\begin{array}{l}\text { Models are made with } \\
\text { different surface color } \\
\text { (Black, gray, White) }\end{array}$ \\
\hline Window & & No filter \\
\hline Scale model & & $1: 20$ \\
\hline $\begin{array}{l}\text { Model } \\
\text { material }\end{array}$ & & Gray cardboard (+paint) \\
\hline $\begin{array}{l}\text { Calculating } \\
\text { Instrument }\end{array}$ & & Light meter digital \\
\hline \multicolumn{3}{|c|}{ Software: Dialux } \\
\hline $\begin{array}{l}\text { Calculation } \\
\text { type }\end{array}$ & & $\mathrm{DF} \& \mathrm{E}$ \\
\hline Sky model & & Overcast sky \\
\hline $\begin{array}{l}\text { Calculation } \\
\text { options }\end{array}$ & & Very accurate \\
\hline $\begin{array}{l}\text { Room } \\
\text { material }\end{array}$ & $\begin{array}{l}\text { Internally } \\
\text { reflection }\end{array}$ & $\mathrm{e}=4 \%, 30 \%, 70 \%$ \\
\hline \multirow{5}{*}{ Window } & $\begin{array}{l}\text { Transmissio } \\
\mathrm{n} \text { factor }\end{array}$ & $100 \%$ \\
\hline & $\begin{array}{l}\text { Transparenc } \\
\text { y factor }\end{array}$ & $100 \%$ \\
\hline & $\begin{array}{l}\text { Reflection } \\
\text { factor }\end{array}$ & 0 \\
\hline & $\begin{array}{l}\text { Pollution } \\
\text { factor }\end{array}$ & None \\
\hline & $\begin{array}{l}\text { Framing } \\
\text { factor }\end{array}$ & 1.00 \\
\hline Maintenance & & 1.00 \\
\hline \multicolumn{3}{|c|}{ Software: Velux } \\
\hline $\begin{array}{l}\text { Calculation } \\
\text { type }\end{array}$ & & $\mathrm{DF} \& \mathrm{E}$ \\
\hline Sky condition & & Overcast sky \\
\hline $\begin{array}{l}\text { Render } \\
\text { resolution }\end{array}$ & & High \\
\hline $\begin{array}{l}\text { Room } \\
\text { material }\end{array}$ & $\begin{array}{l}\text { Internally } \\
\text { reflection }\end{array}$ & $\mathrm{e}=4 \%, 30 \%, 70 \%$ \\
\hline Window & $\begin{array}{l}\text { Transmittan } \\
\text { ce }\end{array}$ & 1.00 \\
\hline
\end{tabular}

\section{Daylighting Calculation Result}

\section{DF and CU Comparison}

Table 3. Light Pattern Comparison

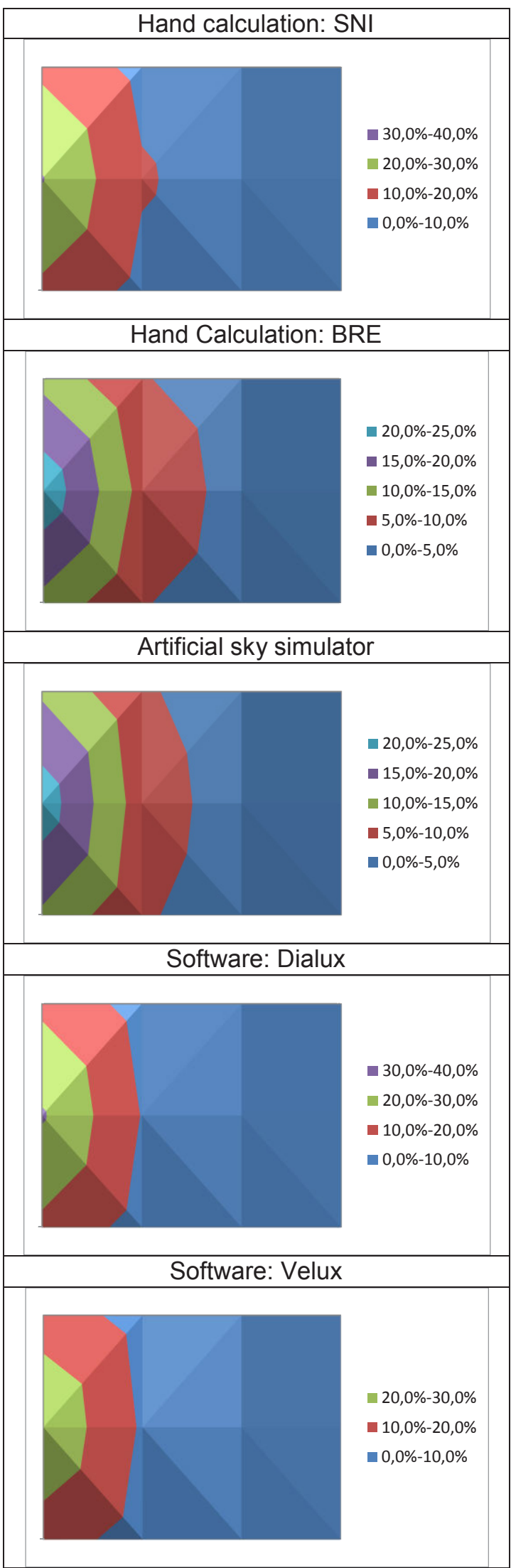




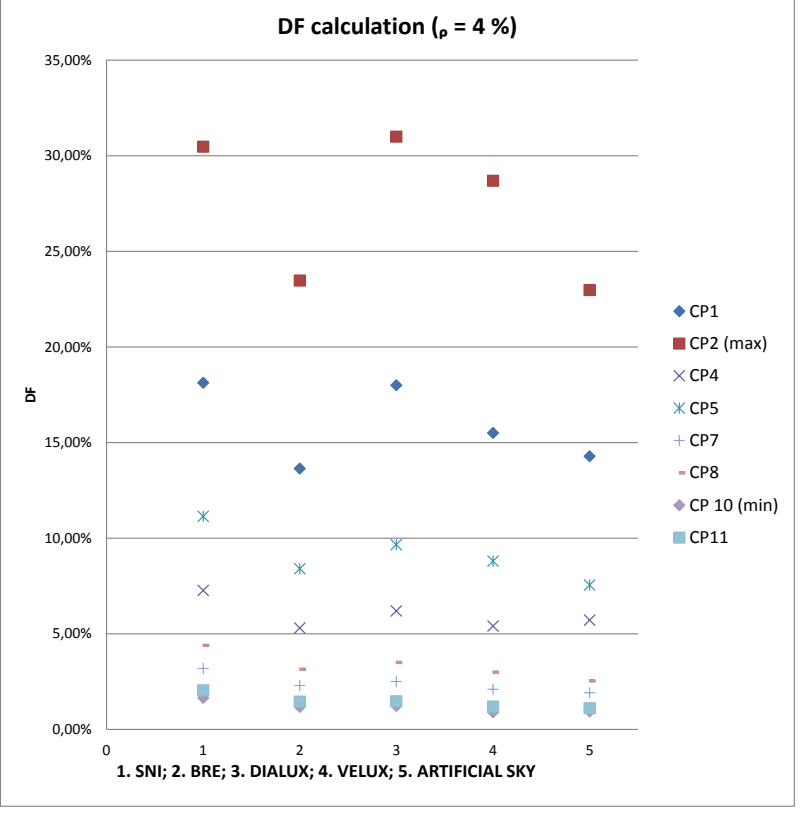

Fig. 7. DF Calculation Pattern (e $=4 \%)$.

The results obtained in DF calculation on black room surface show the similarity of the light pattern on five calculation methods (Table 3). The higher luminance level is reached near the opening's area. The DF range is from $20 \%$ $30 \%$ on the highest measurement point value $(\mathrm{CP} 2)$ and the lowest value is around $1 \%$ (CP 10 or 12). As is observed, $\mathrm{SC}$ value of the SNI method is relatively higher in all measurement points compared to the DF value from other methods. This is contradictory, since SC scores only light from the sky factor and does not count the internally reflection factor from room surface. In this trial, room surfaces are painted in Black with reflection contribution $4 \%$ based on Lechner (2015:407). Although the value is small, the DF value obtained is supposed to be higher than SC value. A study about logarithmic calculations used in the SNI / DPMB sky factor table is required for further analysis. BRE also has a sky factor table with different SC values with SNI sky factor table. BRE sky factor values are lower than the SNI sky factor table value. This result shows the importance of national standard evaluation that still referring to SNI calculation.

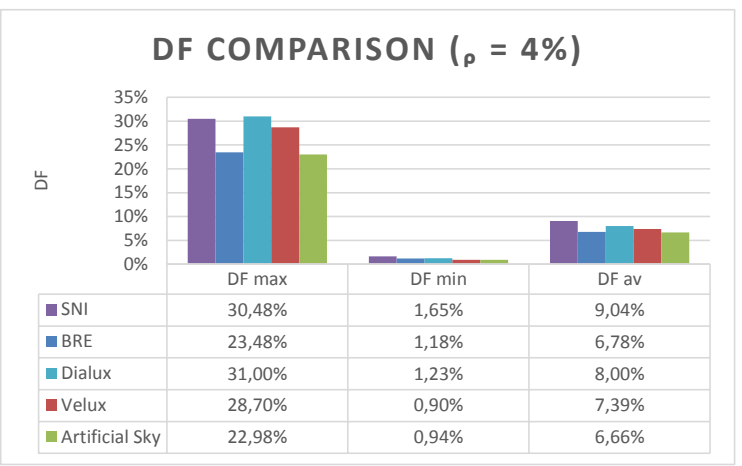

Fig. 8. DF max, DF min, DF average graphic (e $=4 \%)$.

It can clearly be observed in figure 8 that DF values are variable. Overall, the maximum SC / DF levels and average DF level of SNI method are practically close to the software result. While the measurement with the artificial sky simulator are close to BRE result. Minimum DF levels of each method are relatively close, but SNI result is still has the highest value.

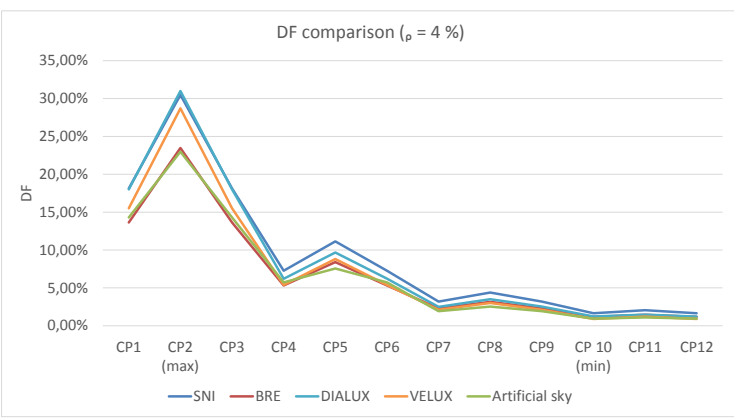

Fig. 9. DF at Each Calculation Points $(e=4 \%)$.

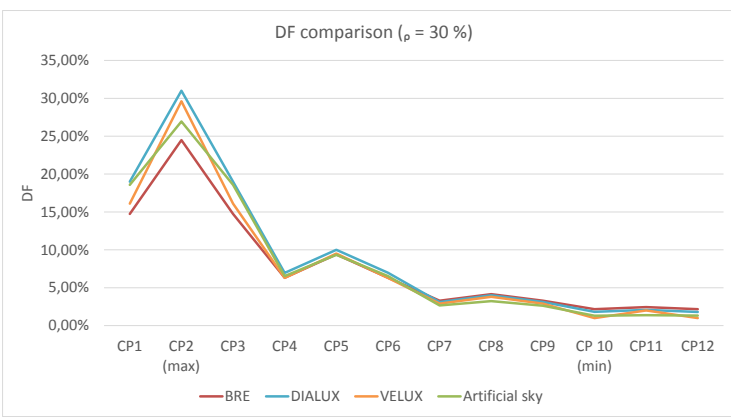

Fig. 10. DF at Each Calculation Points $(e=30 \%)$.

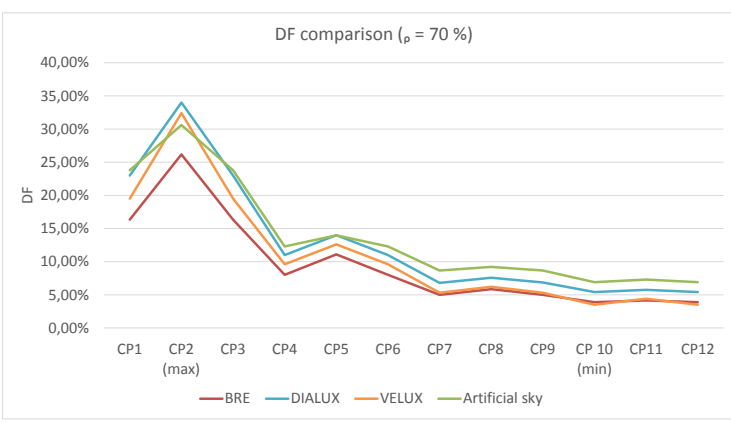

Fig. 11. DF at Each Calculation Points $\left({ }_{e}=70 \%\right)$.

$\mathrm{DF}$ values of software simulation on $\mathrm{CP} 1, \mathrm{CP} 2$, and CP 3 (measuring points position are close to the window) have higher than the DF values of BRE and artificial sky result. However, DF values on other points are relatively having a constant result. These findings need further research to explore and observe.

Another finding is that the DF value of the model with the higher room reflection (painted in white) of the artificial sky result is much higher than the other methods result. Otherwise in the model with medium room reflection factor (painted in gray), DF value tends to be lower than other calculations. This significant difference occurs in the area away from the openings. A Research by Acosta (2011) show that the DF value of the artificial sky calculation is relatively higher than obtained by other methods (he compared with various computer simulation programs). As is observed, this condition may be caused by imprecise model making from the difference between color selected for a room 
model in artificial sky and others method. On BRE, Velux, and Dialux method, the use of reflection factor coefficients can be appropriately taken into account. BRE method has table coefficient value of $30 \%$ and $70 \%$. The software program can set the glass material transmission value manually according to desired coefficient. The paint color chooses in artificial sky model paint has many variants and its difficult to get the reflection precise coefficient that suitable to the needs. The luminance meter instrument should be used in future research to occur more accurate result.

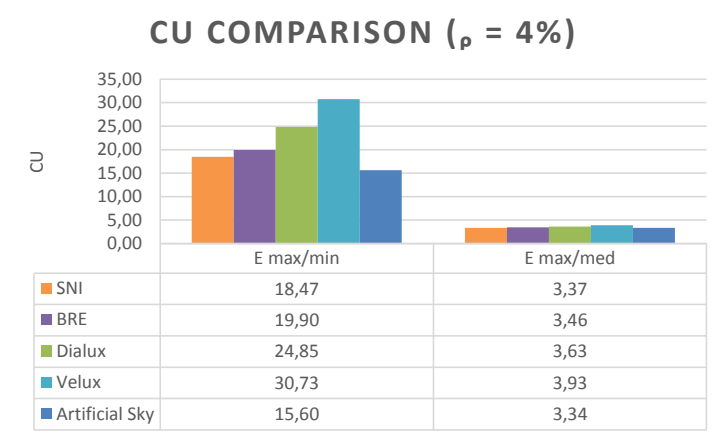

Fig. 12. CU Comparison $(e=4 \%)$.

This study also analyzed the coefficient of uniformity value in each method. The result shows the max/min illuminance level are variable between five methods while max/med illuminance level are relatively similar. Velux program has a higher CU than other methods, while those obtained with the artificial sky method are the lowest.

\section{Room Reflection Trial}

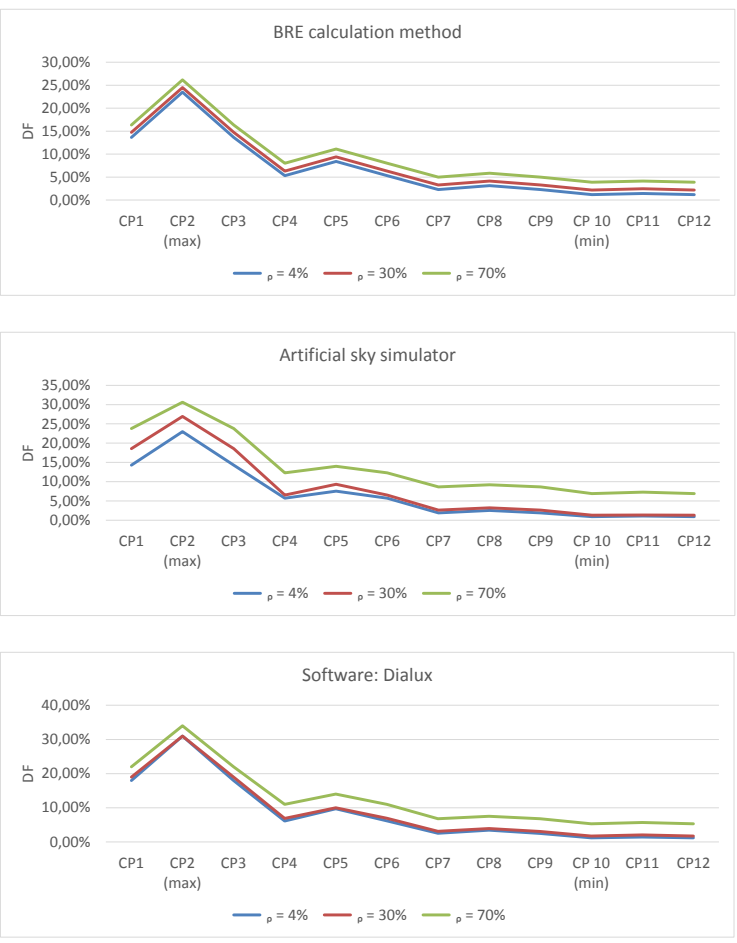

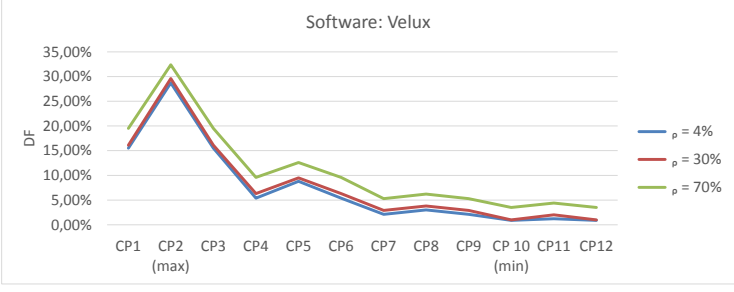

Fig. 13. Room Reflectance Contribution to DF Value (comparison methods).

The comparison of the daylight factor values with different room reflection factors in each method shows at figure 13. As observed above, DF values pattern shows in three room models are similar between those methods. The DF values are significantly increasing in white-painted room surface than others. Another finding is that the DF values increasing are higher at the measurement points away from the opening. The maximum DF in the white-painted room model rose to $26-34 \%$ from the original $23-31 \%$, while the minimum DF value rose to $3.5-6.9 \%$ from the original ranged from 0.9 to $1.65 \%$.

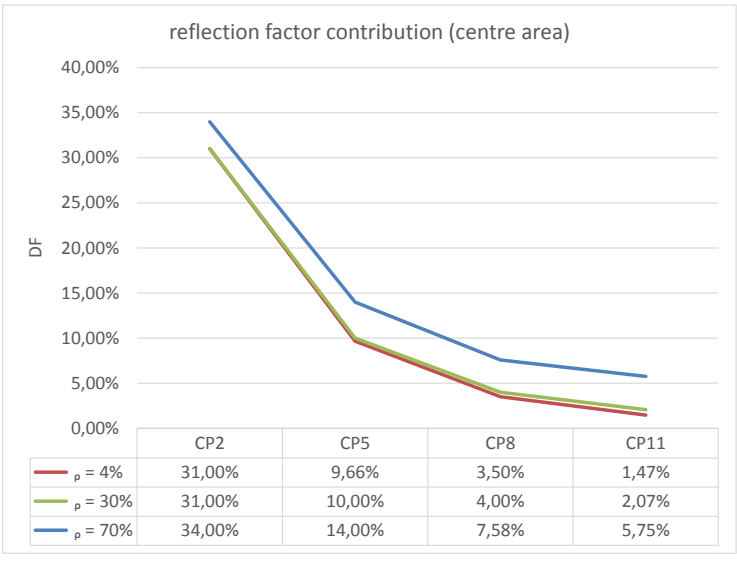

Fig. 14. Room Reflectance Contribution to DF Value at Centre Area.

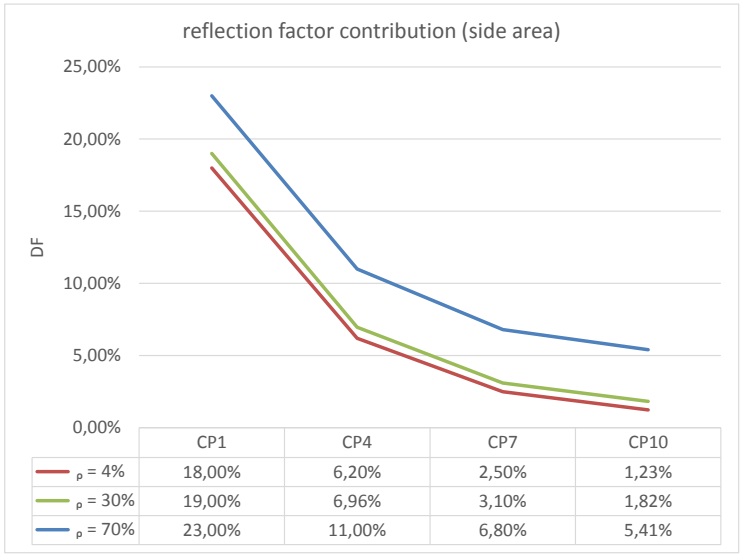

Fig. 15. Room Reflectance Contribution to DF Value at Side Area.

The trial also shows the differences in the contribution of DF values to the measuring point areas at the edge and center of the room. To analyze this, we take data from 
Dialux simulation for quick and precise calculation. The illuminance increasing is more significant in the center area than the edge area. This is due to the spatial element that contributes to the increase of the DF value is higher than the edge area. It has a wider reflection element (ceiling, wall, and floor) and a closer position to the reflecting plane so as to obtain a greater reflection value.

The surface changing from gray to white color shows more significant illuminance increasing than the change from black to gray color. Changes from black to gray contribute to increase the DF value up to $48 \%$. While the change of gray to white color can increase the DF value of 10 to $178 \%$ in the center area and increased by 21 to $197 \%$ at the edge. Thus it can be concluded that the color changing from black to gray is able to increase the illuminance up to $50 \%$, while the color changing from gray to white contributes to increase the DF value much larger that is up to $200 \%$.

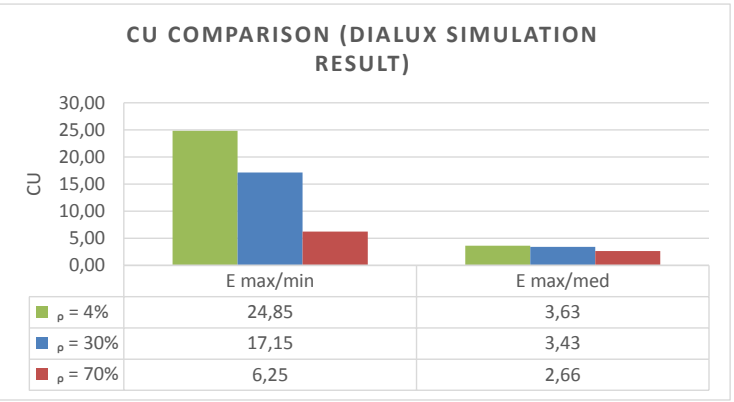

Fig. 16. Room Reflectance Contribution to CU Value (Dialux simulation result).

Figure 16 shows the room reflectance contribution to CU value based on Dialux simulation. As a result, CU value is decreasing (the light is more evenly distributed) at the higher room reflection. The color changing from black to gray contribute to reduce the maximum/minimum illumination value by $31 \%$, while the change of gray to white contributes to reduce the value of $\mathrm{CU}$ two times greater.

\section{Conclusions}

By comparing the five daylighting calculation methods under overcast sky conditions and analyze the room reflection trial result, we can point several conclusions:

1. All calculation methods display similar light distribution patterns, but have varied results in DF and $\mathrm{CU}$ values.

2. Overall, the SC / DF maximum and DF average values by the SNI method are close to the computer simulation results. While the artificial sky measurements are close to the result with the BRE calculation method.

3. In the CU calculation, Velux software has a higher results than the rest. While others are relatively similar.

4. This observation confirms the results of previous studies on the contribution of room surface to the DF and $\mathrm{CU}$ value. Higher reflection factor contributes to increase the illumination and lowering the $\mathrm{CU}$.
5. The contribution of DF values increasing is more significant seen in/at:

○ The gray to white painted model than the black to gray one,

○ Measuring points away from the window that near the window,

○ The Centre than the edge of the room.

6. White painted room $\left({ }_{0}=70 \%\right)$ could increase the DF value up to 3 times and lowering the maximum/ minimum illumination value up to $75 \%$ than a black painted room.

\section{References}

Acosta, Ignacio, et al (2011), Towards an Analysis of Daylighting Simulation Software, Energies 2011, 4, 1010-1024; doi:10.3390/en4071010 published 29 June 2011

Badan Standarisasi Nasional Indonesia (2001), SNI 032396-2001 Tata Cara Perancangan Sistem Pencahayaan Alami Pada Bangunan Gedung, Jakarta

D. H. Koenigsberger, et al (1975), Manual Of Tropical Housing And Building, Universities Press: Hyderabad, India

Dialgmbh (2011), Dialux version 4.9-The Software Standard For Calculating Lighting Layouts-User Manual, Ludenscheid

Direktorat Penyelidikan Masalah Bangunan (1981), Penerangan Alami Siang Hari Dari Bangunan, Bandung: Yayasan Lembaga Penyelidikan Masalah Bangunan

Direktorat Penyelidikan Masalah Bangunan (1989), Tata Cara Perancangan Penerangan Alami Siang Hari Untuk Rumah Dan Gedung, Jakarta

Fullermore (1985), Concept And Practice Of Architectural Daylighting, Van Nostrand Reinhold Company: New York

Geebelen, Benjamin (2003), Daylighting Comuptation Methods (From Do Chart To Digital Simulation), K.U Leuven

Iversen, Anne Et Al (2013). Daylight Calculation In Practice: An Investigation of the Ability of Nine Daylight Simulation Programs to Calculate the Daylight Factor in Five Typical Rooms,. Danish Building Research Institute: Aalborg University Copenhagen

Kota, Sandeep; Haberl Jeff.S (2009), Historical Survey Of Daylighting Calculations Methods And Their Use In Energy Performance Simulations, Proceeding Of Ninth International Conference For Enhance Building Operations, Texas November 17-19,2009

Lechner, Norbert (2007), Heating, Cooling, Lighting. Terjemahan Oleh Sandriana Siti. Jakarta: Pt. Rajagrafindo Perkasa.

Lechner, Norbert (2015), Heating, Cooling, Lighting. New Jersey: John, Wiley\& Sons

Mandala, Ariani (2016), Komparasi Metode Perhitungan Pencahayaan Alami. Research Report LPPM Universitas Katolik Parahyangan: Bandung 
Mandala, Ariani (2017), Komparasi Hasil Kalkulasi Pencahayaan Alami Dengan Metode Manual, Simulasi Maket, Dan Simulasi Komputer. Research Report LPPM Universitas Katolik Parahyangan: Bandung

Phillips, Derek (2004), Daylighting: Natural Light In Architecture. Oxford: Elsevier Ltd 